\title{
The output of Environmental Goods and Services Sector in Poland
}

\author{
Elzbieta Broniewicz \\ Bialystok University of Technology \\ Poland, \\ e.broniewicz@pb.edu.pl
}

\begin{abstract}
The main objective of this paper is to present the output of Environmental Goods Central Statistical Office. The aim of this project was to adapt the Eurostat methodology of EGSS accounts to Polish conditions and to gather data about EGSS, in accordance with the Regulation of the European Parliament and of the Council (EU) No 538/2014 as of 16 April 2014 amending Regulation. Output of Environmental Goods and Services System covers environmental protection domains and also the domains of natural resources management. The results of the survey are also presented broken down by types of economic activity.
\end{abstract}

Keywords: output, environmental economic accounts, environmental goods and services sector, national accounts

JEL: O44, Q56

\section{INTRODUCTION}

The growing awareness of environmental problems and the efforts to remedy excessive emissions have created a comprehensive industry producing environmental goods and services. These are the products that one way or another contribute to environmental protection, limit harmful emissions, re-establish already damaged environment or manage resources. This industry is called the Environmental Goods and Services Sector (EGSS) and it is becoming more and more important in many economies (Jensen and Månson, 2012). Interest in the sector of environmental goods and services was initiated in the early 1990s by the Organization for Economic Cooperation and Development (OECD) and the European Commission. In 1999 a joint (OECD and Statistical Office of the European Union Eurostat) manual The Environmental goods and services industry: Manual for data collection and analysis was published. According to this handbook several European Union countries conducted pilot studies, bringing their experience to the DirectorateGeneral for Environment in European Commission, which also had conducted research in this area. The results were published in Handbook of the environmental goods and services sector (Eurostat, 2009) and in a document titled Practical guide towards compiling the Environmental Goods and Services Sector (EGSS) statistics (Eurostat, 2014). The latter combined two approaches - of the Eurostat (the handbook as of 2009) and 
a global one (including the United States, the European Commission, the OECD and the World Bank best practices) as of 2012, expressed in a document titled System of Environmental-Economic Accounting 2012. Central Framework (SEEA) (UN, 2014).

The legal basis for the development of sector accounts in goods and environmental services sector (EGSS) in the European Union is the Regulation of the European Parliament and of the Council (EU) No 538/2014 as of 16 April 2014 amending Regulation (EU) No 691/2011 on European environmental economic accounts (UN, 2014). The Regulation concerns three modules: a module for environmental protection expenditure accounts, a module for physical energy flow accounts and a module for environmental goods and services sector accounts. Poland has already complied with the obligation to research and transmission to Eurostat information about the first two modules. As regards the EGSS module, the first transmission of data should take place in 2017 and apply to 2015. It requires statistics on environmental goods and services records and presents data on production activities of national economy that generate environmental products in a way which is compatible with the data reported under ESA (European System Accounts).

This paper presents key definitions, methodology, data sources and results of the pilot survey, conducted in 2014-2015 in Poland, as well as international comparisons. This paper presents the results for Poland only, however, the overall analysed subject in view is global production (output) of environmental goods and services.

\section{COMPILATION OF EGSS ACCOUNTS - METHODOLOGY}

Methodological basis of EGSS was included in the Eurostat manuals (Eurostat, 2009). EGSS accounts are written in the Eurostat questionnaire: Environmental Goods and Services Sector (EGSS) (Eurostat, 2015b). Another important document is The list of environmental products (Eurostat, 2015a).

The environmental goods and services sector consists of a heterogeneous set of producers of technologies, goods and services who undertake activities to measure, prevent, limit, minimise or correct environmental damage to water, air and soil, as well as problems related to waste, noise and eco-systems. This includes cleaner technologies, goods and services that reduce environmental risk and minimise pollution and resource use.

Products and services related to environmental protection represent the following categories:

1. specific services - characteristic activities where the purpose is an environmental purpose - e.g.: wastewater treatment, waste management, organic farming, energy production from renewable resources, monitoring, measurement, education, training, etc.;

2. connected products - services or goods directly serve the environment and have no other use except for environmental protection or resource management;

3. adapted products - goods alternative to traditional products, which are more environmentally friendly, less polluting or more resource-efficient than equivalent ordinary goods,

4. environmental technologies - technical processes, installations and equipment (goods) as well as methods or knowledge (services), the technical nature or purpose of which is environmental; environmental technologies can be classified as:

- end of the pipe technologies: technical installations and equipment produced for environmental measurements, control. Also they reduce emissions, environmental degradation and resource depletion. These installations operate independently and identifiable parts are added to the production cycles. For example: facilities for specific environmental services (wastewater and waste), equipment for measurement and control;

- integrated technologies: technical processes, methods and knowledge in manufacturing processes are cleaner and less polluting than the equivalent ones in the typical technology used by national produc- 
ers. For example, in agriculture sector - those that reduce and minimise the negative impact of agriculture on the quality of soil (e.g. organic farming), in industry - those that result in the most ecoefficient industrial processes (e.g. dry ovens compared to wet ovens in cement manufacturing) etc.

These products (i.e. goods and services) and technologies must satisfy the main purpose criterion, i.e. they must have an environmental protection or resource management purpose (hereinafter 'environmental purpose') as their prime objective (Eurostat, 2009).

The EGS activity is classified in two main groups:

I. Environmental protection - includes all activities and actions which have as their main purpose the prevention, reduction and elimination of pollution and of any other degradation of the environment. Those activities and actions include all measures taken in order to restore the environment after it has been degraded. EGSS products are broken down by domains in accordance with The Classification of Environmental Protection Activities (CEPA):

1. Protection of ambient air and climate

2. Wastewater management

3. Waste management

4. Protection and remediation of soil, groundwater and surface water

5. Noise and vibration abatement

6. Protection of biodiversity and landscapes

7. Protection against radiation

8. Research and development $(\mathrm{R} \& \mathrm{D})$

9. Other

II. Resource management - includes the preservation, maintenance and enhancement of the stock of natural resources and therefore the safeguarding of those resources against depletion EGSS products are broken down by domains in accordance with The Classification of Resource Management Activities (CReMA):

10. Management of water

11. Management of forest resources, in it: 11A. Management of forest areas, $11 \mathrm{~B}$. Minimisation of the intake of forest resources

12. Management of wild flora and fauna

13. Management of fossil energy resources, in it: 13A. Production of energy from renewable sources, 13B. Heat/Energy saving and management, 13C. Minimisation of the intake of fossil resources as raw material

14. Management of minerals

15. Research and development $(\mathrm{R} \& \mathrm{D})$

16. Other

The accounts of EGSS consist of the following components: output (including exports), value added and employment. As it is written in the introduction focusing on output, one can distinguish:

- market production - involves selling a technology/product at a price that is economically significant, namely the sale covers more than 50 percent of the production costs; the price considered is the price excluding value added tax or subsidies;

- non-market production - provides technologies or products freely or at an economically insignificant price;

- output for own final use - is to be valued at the basic prices of similar products sold on the market or by the total costs of production, e.g. using renewable energy for own final use;

- ancillary production - exists solely to support the main productive activities of an entity by providing goods or services for the use of that entity (Eurostat 2009, 2015b). 


\section{RESULTS OF THE SURVEY AND DISCUSSION}

Although the general methodology has been developed by European Commission, each EU country must adapt it to their conditions. The great challenge is to find the proper data source. According to the Regulation (EC, 2014) the environmental goods and services sector accounts should make use of the already existing information from the national accounts, structural business statistics, business register and other sources. Unfortunately, timeliness or level of detail in each country does not allow for the direct use of data. Table 1 presents data sources used in the pilot project in Poland.

Table 1

EGSS data map for Poland

\begin{tabular}{|c|c|c|c|c|c|}
\hline Domains & $\begin{array}{c}\text { Market and non- } \\
\text { market production } \\
\text { of wastewater, } \\
\text { waste and water } \\
\text { management service }\end{array}$ & $\begin{array}{l}\text { Market production of } \\
\text { EGSS other than waste- } \\
\text { water, waste and water } \\
\text { management services: non- } \\
\text { capital goods and services }\end{array}$ & $\begin{array}{l}\text { Market produc- } \\
\text { tion of EGSS: } \\
\text { capital goods } \\
\text { and services }\end{array}$ & $\begin{array}{c}\text { Non-market } \\
\text { production other } \\
\text { than wastewater, } \\
\text { waste and water } \\
\text { management } \\
\text { services }\end{array}$ & $\begin{array}{l}\text { Ancillary } \\
\text { production } \\
\text { of EGSS }\end{array}$ \\
\hline CEPA 1 & & $\begin{array}{c}\text { JQ_FP, NA_64_c, VNAS, } \\
\text { NA_SUT }\end{array}$ & \multirow{7}{*}{$\begin{array}{c}\text { JQ_INV, } \\
\text { NA_64_c, } \\
\text { NA_SUT, } \\
\text { NA_21_GFCF, } \\
\text { VNAS, SBS, } \\
\text { PRODPOL }\end{array}$} & EPEA & \multirow{7}{*}{ JQ_ICE } \\
\hline CEPA 2 & \multirow{2}{*}{ EPEA } & \multirow{2}{*}{ data not applicable } & & \multirow{6}{*}{ EPEA } & \\
\hline CEPA 3 & & & & & \\
\hline CEPA 4 & & $\begin{array}{c}\text { JQ_FP, NA_64_c, VNAS, } \\
\text { NA_SUT, AGRI }\end{array}$ & & & \\
\hline CEPA 5 & & \multirow{3}{*}{$\begin{array}{c}\text { JQ_FP, NA_64_c, VNAS, } \\
\text { NA_SUT }\end{array}$} & & & \\
\hline CEPA 6 & & & & & \\
\hline CEPA7-9 & & & & & \\
\hline CReMA 10 & EPEA & data not applicable & $\begin{array}{l}\text { NA_64_c, NA } \\
\text { SUT, VNAS, } \\
\text { PRODPOL } \\
\text { NA_21_GFCF }\end{array}$ & & EPEA \\
\hline CReMA 13A & & $\begin{array}{c}\text { JQ_FP, NA_64_c, VNAS, } \\
\text { NA_SUT, ENSTAT }\end{array}$ & $\begin{array}{l}\text { NA_64_c, } \\
\text { NA_SUT, }\end{array}$ & & \multirow{5}{*}{$\begin{array}{l}\text { data not yet } \\
\text { identified }\end{array}$} \\
\hline CReMA 13B & & & NA_21_GFCF, & data not yet & \\
\hline CReMA 13C & & $\begin{array}{c}\text { JQ_FP, NA_64_c, VNAS, } \\
\text { NA_SUT, ENSTAT }\end{array}$ & $\begin{array}{c}\text { VNAS, } \\
\text { PRODPOL, } \\
\text { CONST, FOST }\end{array}$ & identified & \\
\hline CReMA 14 & & \multicolumn{3}{|c|}{ included in CEPA3 } & \\
\hline Other CReMA & & \multicolumn{3}{|c|}{ data not yet identified } & \\
\hline
\end{tabular}

Legend:

\begin{tabular}{l}
$\square=$ empty cell by definition \\
\hline \hline = suitable data or methods not yet identified or tested by Eurostat
\end{tabular}

JQ_ICE: JQ EPER, internal current expenditure - CSO Poland

JQ_FP: JQ EPER, fees and purchases - CSO Poland

JQ_INV: JQ EPER, investments - CSO Poland

NA_64_c: National accounts by 64 branches at current prices (production and generation of income accounts) - Eurostat database

NA_21_GFCF: National accounts by 21 branches, gross fixed capital formation by type of assets - Eurostat database

NA_SUT: Supply and use tables - output and intermediate consumption by industries/products and final uses and external trade by products - CSO Poland

SBS: $\quad$ Structural Business Survey - Eurostat database

PRODPOL: Production of manufactured goods (Polish version of PROCOM) - CSO Poland

EPEA: $\quad$ Environmental Protection Expenditure Accounts - CSO Poland 
ENSTAT: $\quad$ Energy statistics (energy statistics - production, capacities) - CSO Poland

AGRI: $\quad$ Agricultural statistics (land use, farm accountancy) - CSO Poland

VNAS: $\quad$ Various national sources

EPE: $\quad$ Surveys of environmental protection and water management expenditures, current expenditure and investments CSO Poland

CONST: $\quad$ Construction statistics - CSO Poland

FOST: $\quad$ Forest statistics - CSO Poland

Source: own elaboration on the basis of (Eurostat, 2014, p.36).

According to Eurostat methodology, we can distinguish two types of environmental products:

1. goods and services that are almost entirely (100\%) environmental goods (e.g. wind turbines, waste collection services),

2. goods and services that are not entirely environmental and for which an EGSS share of less than $100 \%$ would apply (e.g. paper and paper products - from recycled paper, glass fibres - for insulation purposes, construction work for power plants - renewable power plants).

When in case of products entirely environmental, there were no problems with the identification of the output value. In case of other products, the key was to determine the percentage of products that are attributable to environmental protection and resource management. Various national sources (from table 1) were used: branch publications (e.g. Window market in Poland 2012-2014. Forecast 2015-2016), expert opinions and legal acts (e.g. the required level of recycling wood packaging in accordance with the Act of 13 June 2013 on packaging and packaging waste). In several cases, they failed to get the required information, but it seems that the material was not statistically significant, e.g. the value of the soundproofing barriers constructions or storage systems for biogas made from high-tech textiles.

Total output value of environmental goods and services sector (EGSS) in Poland in 2014 was equal to 83573 mio PLN, which represented 4,6\% of GDP. The highest values of EGSS output concerned market production $-91,9 \%$. The lowest share has the production for own final use (use of renewable energy) - fig. 1. In 28 EU countries in 2011 market output comprised 89,9\%, non-market output 7,0\%, but ancillary $3,3 \%$ of total output.

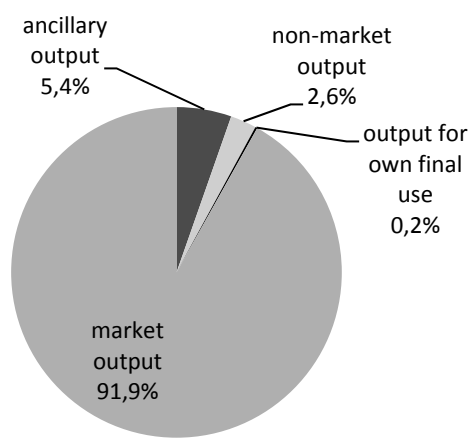

Figure 1. Structure of EGSS output

Source: own elaboration on the basis of Eurostat Database. 
Output of the EGSS can be compiled and cross-classified breaking down into environmental and economic activities. The survey results are shown below. In the tab. 2. one may break down EGSS output by environmental activities, in the tab. 3. it is broken down by industries. All these data in EGSS questionnaire are also cross-classified by environmental and economic activity.

Table 2

Total EGSS output by environmental activity in Poland, 2014 [mio PLN]

\begin{tabular}{|c|c|c|c|c|c|c|c|}
\hline Environmental activity & $\begin{array}{l}\text { TOTAL } \\
\text { Output, of } \\
\text { which: }\end{array}$ & $\begin{array}{l}\text { ancillary } \\
\text { output }\end{array}$ & $\begin{array}{c}\text { non- } \\
\text { market } \\
\text { output }\end{array}$ & $\begin{array}{l}\text { output } \\
\text { for own } \\
\text { final use }\end{array}$ & $\begin{array}{l}\text { market } \\
\text { output, of } \\
\text { which: }\end{array}$ & services & products \\
\hline Protection of ambient air and climate & 8070 & 1843 & 50 & - & 6177 & 608 & 5569 \\
\hline Wastewater management & 10183 & 707 & 141 & - & 9335 & 9057 & 278 \\
\hline Waste management & 8797 & 419 & 101 & - & 8277 & 7049 & 1228 \\
\hline $\begin{array}{l}\text { Protection and remediation of soil, } \\
\text { groundwater and surface water }\end{array}$ & 6127 & 108 & 656 & - & 5363 & 436 & 4927 \\
\hline Noise and vibration abatement & 3249 & 14 & 5 & - & 3230 & 35 & 3195 \\
\hline $\begin{array}{l}\text { Protection of biodiversity and } \\
\text { landscapes }\end{array}$ & 541 & 308 & 111 & - & 122 & 109 & 13 \\
\hline $\begin{array}{l}\text { Protection against radiation; Research } \\
\text { and development (R\&D) and Other }\end{array}$ & 2886 & 385 & 956 & - & 1545 & 1380 & 165 \\
\hline Total CEPA & 39853 & 3784 & 2020 & - & 34049 & 18674 & 15375 \\
\hline Management of water & 12901 & 708 & 116 & - & 12077 & 9965 & 2112 \\
\hline Management of fossil energy resources & 0 & 0 & 0 & 0 & 0 & 0 & 0 \\
\hline $\begin{array}{l}\text { Production of energy from renewable } \\
\text { sources }\end{array}$ & 14271 & : & : & 159 & 14112 & - & 14112 \\
\hline Heat/Energy saving and management & 11037 & $:$ & $:$ & - & 11037 & 920 & 10117 \\
\hline $\begin{array}{l}\text { Minimisation of the intake of fossil } \\
\text { resources as raw material }\end{array}$ & 1754 & $:$ & $:$ & - & 1754 & - & 1754 \\
\hline Management of minerals & 3760 & $:$ & $:$ & - & 3760 & - & 3760 \\
\hline Total CReMA & 43722 & 708 & 116 & 159 & 42739 & 10885 & 31854 \\
\hline TOTAL CEPA and CReMA & 83574 & 4492 & 2136 & 159 & 76787 & 29559 & 47228 \\
\hline
\end{tabular}

Source: own elaboration on the basis of Eurostat Database.

The EGSS output in Poland in 2014 was mainly linked to activities of resources management $(52,3 \%)$. Production of energy from renewable sources had the biggest share $-17,1 \%$ of total output and $18,4 \%$ of market output. 
Table 3

Total EGSS output by economic activity (NACE, Rev.2 (EC, 2008)) in Poland, 2014 [mio PLN]

\begin{tabular}{|c|c|c|c|}
\hline Economic activity NACE & Total CEPA & $\begin{array}{c}\text { Total } \\
\text { CReMA }\end{array}$ & TOTAL \\
\hline TOTAL & 39853 & 43722 & 83574 \\
\hline A - Agriculture, forestry and fishing & 4855 & 417 & 5272 \\
\hline B - Mining and quarrying & 561 & 1369 & 1930 \\
\hline C - Manufacturing & 10579 & 18966 & 29544 \\
\hline D - Electricity, gas, steam and air conditioning supply & 1442 & 10526 & 11968 \\
\hline E - Water supply; sewerage, waste management and remediation activities & 16146 & 6578 & 22724 \\
\hline F - Construction & 1401 & 3732 & 5133 \\
\hline M - Professional, scientific and technical activities & 2366 & 2001 & 4367 \\
\hline O - Public administration and defence, compulsory social security & 1751 & 116 & 1867 \\
\hline Other & 752 & 17 & 769 \\
\hline
\end{tabular}

Source: own elaboration on the basis of Eurostat Database.

The highest values of EGSS output presented above were in NACE C - Manufacturing. The share for these in total output value was at 35,4\% (mainly NACE C2-23-10,3\%, with production of high efficient windows). The lowest shares were in other economic activity ${ }^{1}-0,9 \%$ and the output in this type of economic activity concerns mainly ancillary production.

Distribution of the global output by environmental activity in some UE countries is shown in figure 2 .

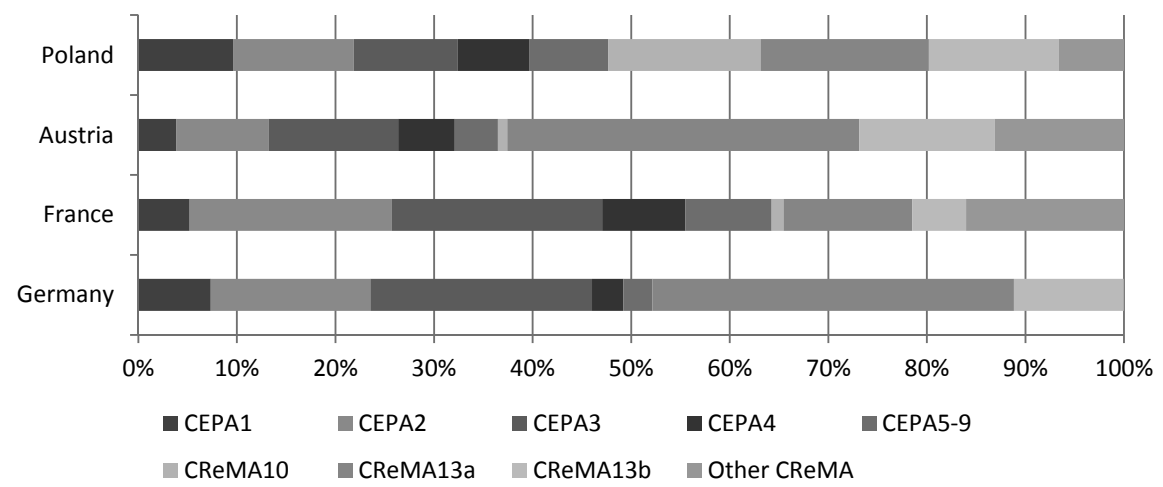

Figure 2. Structure of total EGSS output by environmental activity in UE countries [\%]

Source: own elaboration on the basis of Eurostat Database.

1 NACE section G (Wholesale and retail trade; repair of motor vehicles and motorcycles), H (Transportation and storage), I (Accommodation and food service activities), J (Information and communication), K (Financial and insurance activities), L (Real estate activities), N (Administrative and support service activities), P (Education), Q (Human health and social work activities), R (Arts, entertainment and recreation), S (Other service activities), T (Activities of households as employers; u0ndifferentiated goodsand services-producing activities of households for own use) and $U$ (Activities of extraterritorial organisations and bodies). 
It appears that in each country the main environmental activities are waste and wastewater management (from CEPA), and heat/energy saving and management, minimisation of the intake of fossil resources such as raw material (from CReMA).

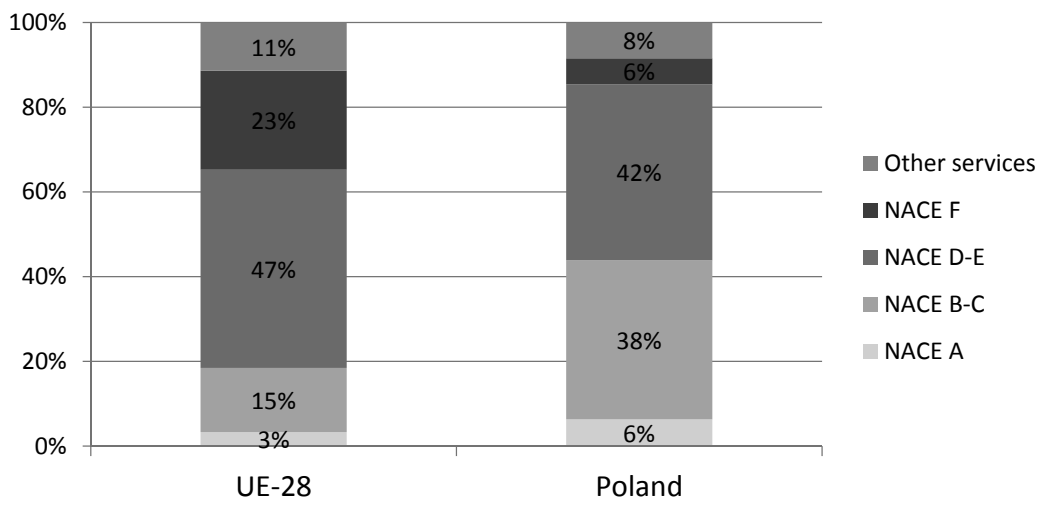

Figure 3. Structure of total EGSS output by economic activity in UE-28 and Poland [\%] Source: own elaboration on the basis of Eurostat Database.

Both in UE-28 and Poland, Electricity, gas, steam and air conditioning supply and Water supply; sewerage, waste management and remediation activities had the biggest share in total EGSS output. It is worth noting that this is rather a small share of global output - NACE F Construction in Poland - $6 \%$ versus $23 \%$ in UE-28. This may be due to the fact that a large part of construction services is carried out by small firms employing less than 10 people, which are not included in the statistical reporting. Unfortunately, there are no previous results of survey, so the comparison is not possible.

Development of the methodology for compiling data on the EGSS output in Poland is the first step to systematic actions in this regard. The output of the EGSS in the European Union in 2004-2013 has more than doubled. All kinds of activities could be observed growth (Figure 4).

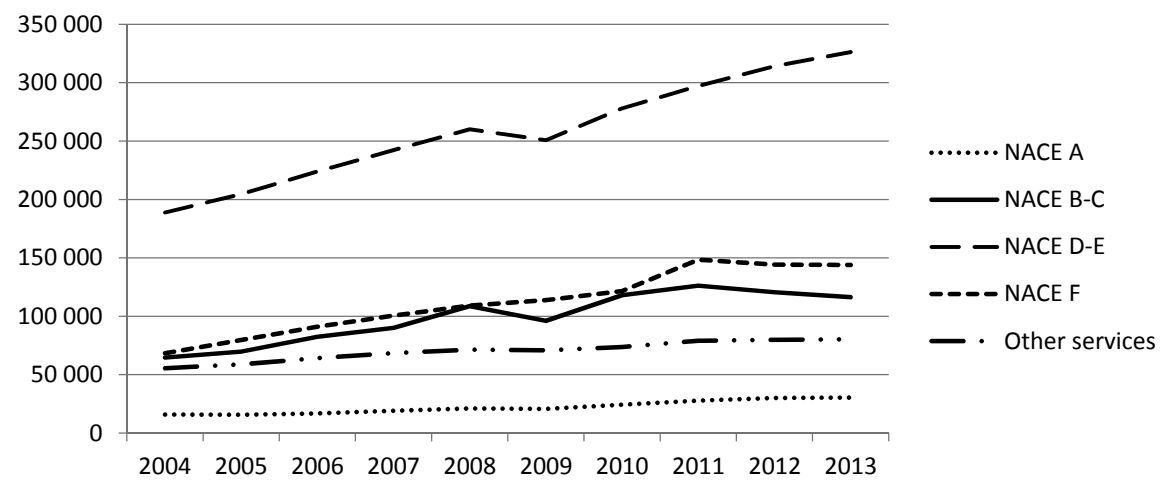

Figure 4. EGSS output in UE countries in 2004-2013 [mio euro]

Source: own elaboration on the basis of Eurostat Database. 
It will be interesting to observe the trend occurring in Poland. Central Statistical Office, following the provisions of the Regulation 538/2014 will undertake an annual survey of this sector in Poland.

\section{CONCLUSIONS}

The presented results of pilot studies on the EGSS concern only one year (2014). The aim of this study was to define the methodology for compiling EGSS accounts and develop a pattern of conduct for the future. In the next years, data, which will be collected by Central Statistical Office in Poland by means of the annual survey on EGSS, will create the basis for presentation and detailed analysis of the current situation, changes and development in industry. Therefore they are indispensable for successful management of the economic and environmental policy.

\section{ACKNOWLEDGEMENTS}

The pilot project was conducted in agreement with Eurostat-Central Statistical Office: „European Environmental Economic Accounts - module: Environmental Goods and Services Sector (EEEA-EGSS)" nr 05121.2013.003-2013.344.

\section{REFERENCES}

EC, (2008), Statistical classification of economic activities in the European Community NACE, Rev.2, European Communities, Luxembourg.

EC, (2014), The Regulation of the European Parliament and of the Council (EU) No 538/2014 of 16 April 2014 amending Regulation (EU) No 691/2011 on European environmental economic accounts (L 158, 27.5.2014).

Eurostat Database // http://ec.europa.eu/eurostat/data/database (referred on 15/04/2016).

Eurostat, (2009), Handbook of the environmental goods and services sector, Luxembourg // http://ec.europa.eu/eurostat/web/environment/methodology (referred on 05/04/2016).

Eurostat, (2014), Practical guide towards compiling the Environmental Goods and Services Sector (EGSS) statistics, Luxembourg // http://ec.europa.eu/eurostat/web/environment/methodology (referred on 15/04/2016).

Eurostat, (2015a), EGSS list of environmental products based on CPA and CN - 2015 // http://ec.europa.eu/eurostat/ web/environment/methodology (referred on 15/04/2016).

Eurostat, (2015b), Questionnaire Environmental Goods and Services Sector (EGSS), Eurostat // http://ec.europa.eu/ eurostat/web/environment/methodology (referred on 15/04/2016).

Jensen P. R., Månsson H., (2012), The Environmental Goods and Service Sector in Denmark. A Pilot Study. Statistics Denmark, Copenhagen.

UN, (2014) System of Environmental-Economic Accounting 2012 - Central Framework, United Nations, New York // http://unstats.un.org/unsd/envaccounting/seeaRev/SEEA_CF_Final_en.pdf (referred on 05/04/2016). 